\title{
Rozmowy
}

\section{Materia to podstawa. Relacje, reakcje i eksperymenty}

Joanna Rajkowska, Agnieszka Dauksza
Tekst powstał $w$ ramach grantu finansowego ze środków Narodowego Centrum Nauki przyznanych na podstawie decyzji numer DEC-2013/11/N/ $\mathrm{HS}_{2} / 03509$.

TEKSTY DRUGIE 2017, NR 1, S. 421-431

DOI: $10.18318 /$ td.2017.1.33

D yskusja odbyła się 27 czerwca 2016 roku na Uniwersytecie Jagiellońskim w ramach konferencji „Nowa humanistyka".

Agnieszka Dauksza: Czuję się nieswojo, jakbym wchodziła w cudze buty. Mam wrażenie, że tę rozmowę powinna przeprowadzić Joanna Jopek, doktorantka Wydziału Polonistyki UJ, jedna z nielicznych akademiczek, które konsekwentnie badają Twoje działania artystyczne. Jednak Joanna Jopek nie może z Tobą rozmawiać, gdyż nie żyje. Należy o niej mówić i pamiętać także dlatego, że wydała niedawno książkę Wolałabym nie, w której pomieszczono świetny tekst o sprawczości negatywnej i praktykach znikania, które na różnych prawach organizują Twoje działania artystyczne ${ }^{1}$. Joanna Jopek uwewnętrzniła te metody, proponując kod i język, mocno rezonujące z pracą, którą wystawiasz obecnie w Krakowie. Gdy

1 J. Jopek Niby, żeby (...). Joanna Rajkowska i performance zniknięć, w: tejże Wolałabym nie, red. J. Stasiowska, Księgarnia Akademicka, Kraków 2015.
Agnieszka Dauksza biogram na s. 373 .

Joanna Rajkowska - autorka projektów publicznych, obiektów, filmów, instalacji oraz efemerycznych akcji i sytuacji realizowanych w przestrzeni miejskiej, m.in.:

Pozdrowienia zAlej Jerozolimskich (2002), Dotleniacz (2007), Linie lotnicze (2008), Wąwóz (2009), Rydwan (2010), Benjamin w Konyi (2010), Urodzona w Berlinie (2012, VII Berlińskie Biennale), Dziecko Peterborough (2012), Wymuszając cud (2012), Dywan (2014), Pasaż Róży (2014), Trafostacja (2016). 
zaprosiliśmy Cię na konferencję „Nowa humanistyka”, od razu wiedziałaś, co dla nas przygotujesz. Powiedziałaś: przyjadę do Krakowa z Samobójczyniami. Dlaczego nam je przywozisz?

Joanna Rajkowska: Jest oczywiście kilka powodów, dla których dokonałam takiego wyboru. Jednym z nich jest moja, coraz żywsza, pamięć o profesorze Nowosielskim, który uczył tutaj w Krakowie, w Akademii Sztuk Pięknych. Byłam jednym z ostatnich roczników, który przeszedł przez jego pracownię. To jest najważniejsza część mojej edukacji. Im jestem starsza, tym bardziej konceptualizuję tamte działania. Myślę o porankach, gdy Nowosielski przychodził do pracowni i zadawał nam zawsze to samo pytanie - przynajmniej tak to pamiętam. Prosił, żebyśmy stawali się tym, co malowaliśmy; mówił: „Proszę starać się być tym jabłkiem, które pani maluje”. Niemożliwość spełnienia tej prośby stała się jednym z wyzwań, które od tamtej pory mi towarzyszą. Cykl, o który pytasz, Samobójczynie, jest odpowiedzią na tamtą niemożność. Mówi o niemożności, choć na innych prawach: o mojej bezpiecznej pozycji widza, obserwatora, kogoś, kto swoją sztuką odcina kupony od tego, co się dzieje gdzieś indziej na świecie, o tych najbardziej tragicznych wydarzeniach, których jesteśmy świadkami. Tu powstaje kolejne pytanie: czy w ogóle jesteśmy świadkami, a jeśli tak - jakimi? Zajmuje mnie ta niemożność bycia świadkiem, niemożność przekroczenia pewnego progu empatii. Praca mówi więc też o bezsilności, o siatce wydarzeń, które oplatają nasze życia. Faktycznie wykorzystuję zdjęcia, które zapadają w pamięć, nawet nie kolektywną, ale indywidualną pamięć ciała. Jednak motorem tej pracy jest przede wszystkim bezsilność.

Często korzystam w moich działaniach z siły bezsilności. Z faktu, że czegoś nie mogę. Pracuję z niemocą, z niemożliwością. Jeśli znacie moją wcześniejszą twórczość, wiecie, że w roku 2000 zrobiłam dość zabawną pracę, która nazywała się Nigdy nie będę papieżem. Nigdy nie będę Andy Warholem. Dzięki niej wypracowałam technikę ilustrowania niemożności. Była zrobiona podobnie do Samobójczyń, kątowniki ułożone w rząd, dwa zdjęcia ukazujące równoległe symulacje: w jednej z nich byłam Janem Pawłem II, w drugiej Andym Warholem. Sceny te było jednak widać tylko pod pewnym kątem, w innych ustawieniach obrazy znikały. Lubię tę technikę - wykorzystywano ją niegdyś w świętych obrazkach, a współcześnie także w billboardach.

Tutaj wraca perspektywa profesora Nowosielskiego, tradycja ikony i obcowania z obrazem, którą próbował nam przekazać. Zgodnie z tym myśleniem 
to nie my mamy władzę nad obrazem i nie my odczytujemy jego sens, ale to on nas pochłania, rządzi nami, steruje naszymi emocjami i myślami. Interesuje mnie moment przejęcia władzy przez obraz, ten inny porządek procesu odbioru. W zachodnioeuropejskiej teorii i w zachodniej sztuce - przynajmniej tej, którą jest mi dane oglądać - tradycja ikony okazuje się praktycznie nieobecna. A to chyba najcenniejsze w kulturze - pełne uczestnictwo w procesie odbioru, cielesne, zmysłowe i afektywne. Praca o samobójczyniach „przemyca" i uwewnętrznia także ten problem.

Kiedy zatem pytasz o inspiracje tej właśnie serii, całkiem serio stwierdzam, że są nimi zarówno ikony, jak i praca o papieżu oraz o Warholu. Jeśli jednak tamta praca była żartem, to Samobójczynie nie są żartem, są dużo cięższe. Także ja sama jestem dziś dużo cięższa - w tym, co robię i jak o tym myślę.

Jest jeszcze trzecia sprawa. Coraz częściej pracuję w pracowni. Jednocześnie mam bagaż doświadczeń z lat, kiedy uprawiałam przede wszystkim sztukę publiczną - duże, trudne logistycznie, zewnętrzne projekty. Zresztą wciąż intensywnie je realizuję, jednak miewam potrzebę odcięcia się, zamknięcia w studiu i pracy rękami. Co ciekawe, z praktyki działań publicznych przejęłam i wniosłam do pracowni jedną podstawową rzecz: szukania w przestrzeni lub sferze publicznej miejsc, które są czarnymi dziurami, są pozbawione energii lub ich energia jest niedobra. Zdjęcia, które pokazuję w serii, o której rozmawiamy, są taką czarną dziurą, zerowaniem energetycznym, progiem, za którym „nic” nie ma. Gdy na nie patrzę, mam poczucie, że nie można ich dalej pomyśleć, zanalizować, że zatrzymuję się w punkcie, gdzie rozpoczyna się jakieś nieznane. Nie tylko dla tych kobiet, samobójczyń, bohaterek tych zdjęć, ale też dla nas, widzów. Lubię pochylać się nad tymi zdjęciami. I tymi szczątkami. Gdy tnę takie zdjęcie, ciało, nogę, czuję, że dokonuje się proces oddawania władzy obrazowi. Chodzi mi oczywiście o poziom materialny, jestem skupiona na materii, na niczym innym. Przenoszę więc doświadczenie z przestrzeni publicznej w pole pracy studyjnej. Być może zresztą każda sztuka jest w zasadzie oddawaniem czy nadawaniem władzy materii? Czy to materia miejsca, czy obrazu, jest sprawą drugorzędną.

A.D.: Kontynuujmy ten wątek. Twierdzisz, że posiłkujesz się w działaniach artystycznych „zwierzęcym instynktem” $\mathrm{i}$ wielokrotnie podkreślasz, jak istotne jest w Twoich działaniach to, co nieracjonalne, afektywne, emocjonalne. Tropisz niejednoznaczne sytuacje i przestrzenie, zwracasz uwagę na aberracyjny tryb funkcjonowania jednostek i wspólnot. Właśnie w miejscach 
trudnych czy „tkliwych” lokujesz swoje praktyki. Czasami przekonujesz, że jesteś „sejsmografem”, kiedy indziej, że „szamanką". Jeśli po tzw. zwrocie afektywnym rozumiemy zapewne, co masz na myśli, mówiąc o pracy sejsmografu, to jednak drugie określenie wciąż wydaje się jakoś szemrane, wręcz pretensjonalne. Co właściwie rozumiesz jako artystyczny „szamanizm” lub „szamaństwo"?

J.R.: Nieraz dostałam po łapach za to porównanie. Szamaństwo - co to niby ma znaczyć?! Sama nie wiem. Jednak nie cofam tego zdania, choć nie umiem go do końca obronić. Im dłużej pracuję, tym bardziej umacniam się w postawie nieanalitycznej. Moje projekty nie są konsekwencją badań, nie zakładają rezultatu działań, nawet najbardziej ryzykownego. To są otwarte eksperymenty. W moim szamaństwie posługuję się materią (również ciała), obserwuję substancje, które jakoś się zachowują. Założeniem jest oddanie pola temu, czego jeszcze nie znam i nie umiem nazwać. Nie wiem, jak zachowają się ludzie, którzy włączą się do działań, jak zareagują rośliny itd. Zauważ, że większość moich projektów publicznych odnosi się nie tylko do ludzi, ale do materii organicznej w ogóle, żywej i nieżywej. Interesuje mnie, jak te elementy będą wchodzić w reakcje. Stwarzam sytuacje, a potem obserwuję procesy mnożących się relacji, których wynik jest nieprzewidywalny. Jednocześnie używam siebie, własnego ciała jako swego rodzaju filtra, urządzenia, którego odpowiedzi traktuję poważnie i które staram się uwspólnić.

Młodsze pokolenie artystów, młodszych ode mnie o dziesięć lat, zupełnie inaczej aranżuje przestrzeń eksperymentu. Najczęściej mają bardzo mocne punkty wyjścia i wiele mechanizmów opiera się na zasadach gry. W moim przypadku nie ma gry, używam fundamentalnych mechanizmów operujących na styku naszego biologicznego i kulturowego bytu. Wierzę, że sytuacje, które uruchamiam, otwierają w ludziach rozdźwięk między tym, kim są publicznie i tym, kim są „cieleśnie”. Ciekawią mnie momenty, gdy ludzie są obnażeni, pozbawieni narzędzi obronnych i tożsamościotwórczych, kiedy ich fasady zaczynają pękać. Co się z nami dzieje, gdy jesteśmy bezbronni, pozostawieni na pastwę swoich ułomności, niemocy, śmiertelności. W takich chwilach także musimy się wobec siebie jakoś zachowywać. Trudno sterować sytuacjami, gdy jesteśmy po prostu grupą zwierząt. Wówczas moje mgliste założenia i tak okazują się nieprzystające do wydarzeń. Było kilka bardzo wyrazistych chwil, np. przy Dotleniaczu, gdy ludzie przestali się ze sobą komunikować, gdy narzędzie mowy zostało odłożone, gdy skupili się na oddychaniu. To są dla mnie piękne i zaskakujące sytuacje. 
A.D.: Czy pozostajesz tak nieufna wobec języka, jak to zwykle deklarowałaś? Przez lata przekonywałaś, że Twoja sztuka musi wywodzić się z przedjęzykowych odczuć ciała.

J.R.: Chyba to się zmienia. Jeśli chodzi o język, interesują mnie teraz zwłaszcza dwa problemy. Moment, w którym zaczynamy mówić, kiedy dźwięki zaczynają znaczyć, kiedy tworzy się jakiś kod oraz kiedy tracimy mowę. Wzrost oraz erozja języka. Materialność mówienia jest bardziej fascynująca niż sam akt komunikacji, który - szczerze mówiąc - kompletnie mnie nie ciekawi. Prawdą jest, że naszą jedyną ojczyzną jest język i że wszystko jest w języku i z języka. Jestem faszystką językową - język polski jest czymś wspaniałym. Niesamowita jest możność onomatopeicznego wcielania rzeczy w język. To jest materia języka. Sama wizja, że moje dziecko mogłoby nie umieć mówić po polsku, zupełnie mnie przerażała.

Równie ważna jest materialność zapisu. Sposób, w jaki formujemy, kształtujemy litery i połączenia między nimi, między słowami i zdaniami, świadczy o nas i wpływa na naszą percepcję rzeczywistości. W 2010 roku zrobiłam projekt w Turcji podejmujący te wątki, nazywał się Benjamin w Konyi. Przełożyliśmy tekst Waltera Benjamina z oryginału niemieckiego na martwy język otomański. Oczywiście nie byłam w stanie tego sama odczytać, ale znaleźli się starzy Turkowie, którzy znają ten język i którzy potrafili przeczytać zapis. To był wzruszający moment, kiedy tekst żydowskiego filozofa ożywiają religijni muzułmanie i czytają go jako tekst święty.

A.D.: Joanno, mówi się o Tobie nieodmiennie, że jesteś artystką przestrzeni publicznej Faktycznie, jednak nie mogę pozbyć się wrażenia, jak osobiste, wręcz intymne są Twoje praktyki. Napięcie między publicznym i prywatnym, które napędza dynamikę tych działań, uświadomiło mi, że nieustannie nicujesz dualizmy i podziały. Jedną z konsekwencji jest specyficzny status Twoich projektów, które najczęściej są bardzo subtelne, delikatne, słabe w rozumieniu Vattimowskim, choć bywają także subwersywne. Jak sądzisz, czy polskie społeczeństwo, które przywykło przede wszystkim do intensywności wyrazu artystycznego, jest gotowe na odbiór Twojej metody?

J.R.: Myślę, że polskie społeczeństwo nie ma żadnego problemu z przyjęciem takiej strategii. Jak się okazało, w Polsce pracuje się dużo łatwiej niż w Europie Zachodniej, gdzie pozycja artysty wciąż sprowadzana jest do pozycji badacza, który przesuwa elementy na planszy i rozwiązuje kolejne trudności. 
Dominuje retoryka społecznej zmiany, „empowerment through arts”, co jest bardzo męczące. Trzeba wiele tłumaczyć, przekonywać, że artystka nie jest wróżką, która przyleci i pokaże, jak pokonać nawarstwiające się od lat problemy. Irytujące jest również mocne odgradzanie tego, co prywatne i tego, co publiczne. W Polsce te podziały są przyjemnie płynne. W Wielkiej Brytanii np., gdy podejmuje się publicznie temat śmierci dziecka, okazuje się to bardzo źle widziane. Pamiętam, jak mówiłam o tym podczas seminarium na Goldsmiths University of London. Przytoczę usłyszane wówczas zdanie po angielsku, ponieważ ciężko znaleźć polski odpowiednik tego okrutnie akademickiego, biurokratycznego języka. Spytano mnie wówczas: „Is there any public urgency to talk about things like a death of the child?”. W Anglii „public urgency" ma się nijak do „a death of the child”, tam nie ma punktów stycznych. Są dwa różne języki, które przynależą do różnych porządków, które nie mogą mieć ze sobą nic wspólnego.

Opowiadam to, żeby uświadomić, że w Wielkiej Brytanii moja pozycja - nie tylko artystki, ale też „badaczki” - nie może mieć nic wspólnego z moją sytuacją osobistą, z tym, że jestem matką, że mam problem, że zamiast jechać $\mathrm{w}$ teren i robić badania, muszę być $\mathrm{z}$ dzieckiem w szpitalu, co siłą rzeczy znajduje wydźwięk w projekcie, nad którym aktualnie pracuję. Jeśli nie mam warsztatu akademickiego (już nawet nie chcę mieć!), nie jestem w stanie przekonać brytyjskich badaczy sztuki, że moje działania mogą mieć wartość, że doświadczenia osobiste, ciało, macierzyństwo są jeszcze jednym materiałem i narzędziem, z którego można korzystać w pracy. A przecież pod wpływem tych przeżyć zasadniczo zmienia się ogląd spraw, redefiniuje się sposób działania, inaczej postrzega się relacje, nie tylko międzyludzkie, ale też usytuowanie wobec miejsc, roślin i zwierząt.

Wydaje mi się, że mimo wszystko w Polsce nie ma tak ostrej cezury między prywatnym i publicznym, wiele granic jest zamazanych. Nie chodzi mi o poziom emocjonalności. Na tym się nie znam, nie dotykam sfery emocjonalności. Mówię o ciele, które domaga się ekspresji i należy to brać pod uwagę. Ciała kobiet, ciała mężczyzn, dzieci, młodszych i starszych osób wszystkie one coś przekazują i także są materiałem, którego można użyć. Nie widzę więc powodu, dla którego miałabym odcinać się od tych ciał, zacierając ślady procesu mojej pracy. Im więcej prywatności i przyzwolenia na zdjęcie społecznych uniformów w przestrzeni publicznej, tym będziemy szczęśliwsi. 
A.D.: Ewidentnie w swoich praktykach czerpiesz wiele z psychobiologicznych poruszeń i intensywności, ciekawi mnie jednak, jak sytuujesz swojego odbiorcę, czy przewidujesz konkretną pozycję odbiorczą? Czy jest to według Ciebie zupełnie otwarta sytuacja?

J.R.: Widzę na horyzoncie straszne widmo partycypacji... Nie zajmuję się widzami, kompletnie. Wiem, że to jest wbrew podzielanym przez wielu zasadom, ale nie umiem inaczej. Nie mam tego rodzaju wyobraźni, nie umiem zupełnie przewidzieć, co może się wydarzyć. Projekty są najczęściej kolektywne, mam więc tylko wizję, że może zjawi się ktoś, kto przyjdzie, usiądzie, coś zrobi. Ale co zrobi? Tego zupełnie nie wiem.

A.D.: Joanno, chyba jednak kokietujesz. Kiedy np. stawiasz palmę w centrum Warszawy, to musisz mieć świadomość, że wsadzasz drzazgę w oko czy wręcz kij w oko. Potrzeba do takiego gestu pewnego minimum wyobraźni, chyba przyznasz? Bez wyobraźni nie byłoby prowokacji.

J.R.: Tak, ale cały proces projektowania wydarza się wówczas wobec przestrzeni, wobec zbiorowości, a nie wobec konkretnego widza z jego specyficznym aparatem odbiorczym. Gdy pracuje się nad mapami czy nad linią horyzontu miasta lub perspektywą ulicy, to układ budynków jest dużo ważniejszy niż odbiorca, który zjawi się w tym spektaklu. Nie interesuje mnie zupełnie jednostkowy odbiór. Odróżniam tu perspektywę ukontekstowionego widza i dwustronną relację miejsca i człowieka. Miejsca mają nad nami taką samą władzę, jak my nad nimi. Owo „pomiędzy” miejscem i człowiekiem czy zbiorowością jest najważniejsze. Widzę to więc zarazem w skali „mikro”, jak i „makro". Na przykład wyobrażam sobie, jak ktoś będzie oddychał przy Dotleniaczu, ale zatrzymuję się na procesie somatycznym, nie jestem w stanie projektować tego człowieka, nawet bym nie śmiała wyobrażać sobie jego jednostkowego odbioru. Nie mam dostępu do takich, bardzo uwarunkowanych reakcji. Jestem tylko w stanie przewidzieć, że zapewne powstanie coś „pomiędzy”, siła wiążąca miejsce, sytuację i potencjalnego odbiorcę.

Gdybym miała kiedykolwiek uczyć studentów, powiedziałabym im, by nigdy nie robili sztuki z wiedzy, ale właśnie tworzyli z tego, czego nie wiedzą. Żeby ufali przypadkowym, fantasmagorycznym wydarzeniom, złudzeniom, powidokom. Tym, co nam się przewiduje i przywiduje. Tylko wówczas - my, artyści - zyskujemy dostęp do czegoś, co nie jest dostępne innym 
dyscyplinom. Mamy społeczne przyzwolenie, żeby poruszać się w przestrzeni niezdefiniowanego. Jest to niezwykle cenne.

Nie chcę przez to powiedzieć, że np. zachęcam do wycieczek LSD czy do zażywania opioidów, natomiast skłaniam do zachowania czujności wobec rzeczywistości. Tak np. powstała Palma. Wielokrotnie podkreślam: to był żart na zakończenie rozmowy, odpowiedź w sytuacji, gdy nie wiedziałam, co powiedzieć. Było gorąco, a my z Arturem Żmijewskim usiłowaliśmy sensownie dokończyć tekst o Izraelu, o tamtejszym konflikcie, o drugiej intifadzie, o tym, czego byliśmy świadkami.

Bronię mojej pozycji: trzeba ufać intuicji energii, która jest odpowiedzią na inną energię. Nie potrzebujemy do tego super pogłębionej wiedzy i rozległych badań - jestem przekonana, że za pięćdziesiąt lat ze współczesnego splotu sztuki i nauki będziemy się wszyscy śmiać. Z nas samych, artystów będziemy się śmiać. Wy - akademicy macie pełne prawo do swoich badań, wiecie, co robicie. Jednak moment, w którym artyści biorą się za filozofię, naukę lub antropologię, jest faktycznie żenujący. Najczęściej zachowują się jak kompletni dyletanci. Brakuje im odwagi wypracowania własnych metod. Można oczywiście korzystać z określonych narzędzi, ale wypadałoby wiedzieć, jak one działają i do czego mogą służyć. Practice based research jest dobry dla pewnych artystów, o ile praktyka wyprzedza teorię. Jeżeli jest inaczej, to wierzcie mi, efekty są beznadziejne.

\section{A.D.: No dobrze, a jaka jest właściwie Twoja metoda lub metody?}

J.R.: To są raczej małe metody, „metodki”. Jestem skupiona na ciele. Buduję moje projekty, myśląc o procesach wzrostu i procesach starzenia się. Całą uwagę poświęcam wyobrażeniu działania tych mechanizmów, wręcz na poziomie molekularnym. To jest bardzo delikatna metoda, po prostu przenoszę nacisk z badania procesów społecznych na skupienie na procesach organicznych. Interesuje mnie, co dzieje się z materią. Można potraktować teren jako ciało. To zdarzyło się przy Dotleniaczu. W momencie, w którym wbijaliśmy pierwszą łopatę w ziemię placu Grzybowskiego, miałam poczucie, że te prace archeologiczne są wbijaniem kołka osinowego w samo serce wampira, bo grunt tam był wampiryczny. Czułam, że nigdy w życiu nie byłam bardziej precyzyjna. Wywołało to we mnie totalne poruszenie. Byłam pewna, że to jest najbardziej odpowiednie narzędzie do tego miejsca.

Jeśli traktuje się przestrzeń jako organizm, czuje się, gdzie są miejsca słabe, gdzie przebiegają sploty słoneczne, jaką operację należy przeprowadzić. 
To nawet nie jest empatia, ale wiedza ciała. Jeśli przełoży się tę wiedzę na grunt, na którym się pracuje, wszystko staje się jasne. Te metody postrzegania rzeczy organizują chyba wszystkie moje projekty. Gdyby je zestawić, okazałoby się, że mechanizm jest w gruncie rzeczy bardzo podobny. Zastanawiałam się nad tym, pisząc książkę, która ukazała się w Londynie, Where the Beast is Buried. Nie analizuję tam moich prac, ale opowiadam o procesach ich tworzenia. To wiele mi dało, było ożywcze, ponieważ człowiek, pisząc, uruchamia inne moce.

A.D.: Chciałabym na koniec spytać o samotność artystki - wobec instytucji, ale i krytyki. Mam na myśli ciszę, która często zapada po Twoich projektach. Kiedy indziej interpretatorom ewidentnie trudno prześcignąć poziom Twoich własnych autokomentarzy...

J.R.: Palma jest faktycznie mocnym przykładem opuszczenia przez krytykę. Przez ponad dziesięć lat nie pojawiały się analizy projektu. Właściwie do tej pory nie ma ich zbyt wiele, powstał chyba jeden tekst krytyczny... w Nowym Jorku, w The New School for Social Research, zresztą jest to bardzo dobry tekst. Sebastian Cichocki z Muzeum Sztuki Nowoczesnej twierdzi, że dzieje się tak, gdyż moje projekty idą w świat nieopakowane w siatkę teoretyczną. Z premedytacją ich nie wyposażam, nie mam odpowiednich narzędzi, zresztą to nie moja rola. W konsekwencji prace są niechętnie przyjmowane przez instytucje i krytyków. Nikt też nie zamawia tekstów. Jednak te projekty są długodystansowe, starzeją się, ich sensy się nawarstwiają.

Podobnie było w Łodzi, z Pasażem Róży. Ten projekt nie powstał w rezultacie odkrycia kolejnej „czarnej dziury”, wręcz przeciwnie. Okazało się, że moja córka Róża, która jako małe dziecko była bardzo chora - miała nowotwór oczu - jednak będzie widzieć. Jak widzi, to już zupełnie inna kwestia, i tego za bardzo nie jesteśmy sobie w stanie wyobrazić. Jedno oko jest ślepe, drugim widzi i to dobrze, ale trochę inaczej. Gdy już wiedziałam, że będzie widzieć, postanowiłam zrealizować pewną dawną intuicję. Ten sposób myślenia o pracy działa także w przypadku Samobójczyń. Chodzi o kawałkowanie pola widzenia. W Pasażu Róży mamy do czynienia z rozbiciem obrazu na setki tysięcy kawałków, z mozaiką składającą się z pociętych lusterek. Zgadzam się, że może to się wydawać potwornie kiczowate, ale ten kicz, na szczęście, znikł wobec skali projektu, mamy bowiem do czynienia z ponad 800 metrami kwadratowymi powierzchni. Jest to wąski pasaż między kamienicami usytuowanymi blisko siebie. Efekt konwergencji jest niesamowity, odbicia się 
powielają, dobrze to działa. Ktoś powiedział, że gdy człowiek wchodzi w ten Pasaż, to się dematerializuje, po czym na nowo materializuje po drugiej stronie. Faktycznie, jest wrażenie, że ciężka bryła znika, podobnie ściany i powierzchnie. Przestrzeń wydaje się grą odbić. Istotne było uzyskanie wrażenia, że to budynki nas widzą, oddanie władzy budynkom, przekierowanie uwagi. Niedawno pierwszy raz widziałam skończony projekt. Lusterka powoli się przebarwiają i zmieniają odcień.

Szczerze mówiąc, liczyłam na dyskusję o tym projekcie i wspólny namysł z łódzkim Muzeum Sztuki nad tym, co dzieje się w tamtym miejscu. Ale to nie nastąpiło. Łódź woli tradycję awangardy.

A.D.: Powiedz jeszcze, proszę, czym zajmujesz się obecnie? Wiem, że pracujesz we Wrocławiu nad projektem wodnym?

J.R.: Tak, jest to projekt, który zdarza się raz w życiu. Chciałam pracować z lękiem przed wodą. Jak wiecie, Wrocław został zalany w 1997 roku, a według mnie lęk przed wodą już wcześniej budował tożsamość tego miasta. Miałam wiele pomysłów, jak opracować ten problem, np. chciałam zbudować modernistyczną w stylu fasadę i umieścić ją w rzece, ale oczywiście mi nie pozwolono, gdyż to zwiększyłoby zagrożenie powodziowe. W końcu ktoś przesłał mi zdjęcie pewnego budynku stacji transformatorowej, który stoi niedaleko rzeki. Tam właśnie powstaje Trafostacja. Jest to prosty budynek z dwunastoma olbrzymimi oknami. Budynek widmo. Bez drzwi, opuszczony. Zalejemy go wodą, która będzie się nie tyle lała, ile wyraźnie sączyła z okien. Obsadzimy go roślinami, które dobrze reagują na wilgoć, by rozrosły się w budynku i na dachu. Jest to pomysł wymierzony w przyszłość - zastanawiam się, co będzie się działo z budynkiem za dziesięć, dwadzieścia, trzydzieści lat. W momencie otwarcia projekt praktycznie nie będzie gotowy, ponieważ rośliny nie zdążą się zadomowić, nie powstanie ekosystem. Jednak już teraz wyobrażamy sobie, które rośliny przyciągną określone gatunki owadów i ptaków.

Trafostacja jest pokłosiem moich wcześniejszych działań, do których kiedyś zaprosiła mnie Maria Potocka. Chodziło o pracę nad jednym z budynków Fabryki Schindlera, który jeszcze wtedy nie był wpisany do rejestru zabytków. Wówczas pojawiła się intuicja, by przekazać budynek innym gatunkom zalać go wodą, obsiać i zostawić samemu sobie. Nie mogłyśmy zrealizować tego pomysłu, gdyż dość szybko obiekt zmienił swój status prawny. Ale przez wszystkie kolejne lata szukałam budynku, który mogłabym zalać wodą. 
Jednym z najważniejszych aspektów jest więc erozja i starzenie moich projektów. To jest dla mnie niesłychanie ważne, gdyż one starzeją się zawsze wobec kogoś i czegoś, m.in. społeczności, które z nimi na co dzień żyją. Prace ewoluują także pod innym względem, generują nowe znaczenia. Po latach stają się czymś zupełnie innym, np. Palma, która jest świadkinią ważnych wydarzeń, choćby kolejnych fal migracyjnych. Przez lata nasze życie bardzo się zmieni i będzie się zmieniało, diametralnie. To wszystko zapewne jakoś odciska się czy osadza na tym drzewie. Pewnie przyjdzie czas, że i o tym ktoś napisze. Jestem cierpliwa.

A.D.: Joanno, dziękuję za rozmowę.

\section{Abstract}

\section{Joanna Rajkowska}

ARTIST

\section{Agnieszka Dauksza}

JAGIELLONIAN UNIVERSITY (CRACOW)

Matter Is Essential: Relationships, Reactions and Experiments

The point of departure for this interview is the new project Suicidal Women (2016) by the visual artist Joanna Rajkowska, as well as the question of how the image impacts the viewer. For Rajkowska, the reception and description of contemporary art needs to be not merely rational but also based on impression and affect. The interview touches on questions of relationality, materiality and embodiment as essential aspects of the creative process. Rajkowska compares her work to the functioning of a 'seismograph' being sensitive to the energy of spaces that demand artistic intervention. Other topics include the artist's method and tools, her engagement, her critique of participation and of academic training as an artistic tool. The following works by Rajkowska are discussed: Suicidal Women, Greetings from Jerusalem Avenue, I Will Never Be a Pope. I Will Never Be Andy Warhol, Benjamin in Konya, Oxygenator, Rosa's Passage, Trafostationtion

\section{Keywords}

Rajkowska, matter, relationality, embodiment, suicide, visuality 